\title{
The Effect of Work Atmosphere on Career Commitment at Regional Personnel Agency Office in Bima Regency
}

\author{
Ety Kurniawati* \\ Institute of Economic Science of Bima \\ Bima,Indonesia \\ etykurniwati013@gmail.com \\ Mistar Mistar \\ Institute of Economic Science of Bima \\ Bima, Indonesia \\ mistar.stiebima@gmail.com
}

\author{
Muhajirin Muhajirin \\ Institute of Economic Science of Bima \\ Bima, Indonesia \\ Jirin.stiebima@gmail.com \\ Sri Ernawati \\ Institute of Economic Science of Bima \\ Bima, Indonesia \\ sriernawati.stiebima@gmail.com
}

\begin{abstract}
The purpose of this research is to find the effect of the work atmosphere on career commitment at Regional Personnel Agency office in Bima Regency. In this research, the dependent variable used is career commitment while the independent variable is work atmosphere. This type of research is causal associative. The sampling technique used was saturation sampling technique in order to obtain the total sample of 43 respondents with the status of Civil Servants. Regression for this study obtained an equation that is $\mathrm{Y}=16,392+3,739 \mathrm{X}$. The results of this research indicate that the work atmosphere has a positive and significant effect on employee career commitment at Regional Personnel Agency office in Bima Regency.
\end{abstract}

Keywords—component, formatting, style, styling, insert

\section{INTRODUCTION}

The success of an organization is determined by the quality of the people working in the organization itself. As the result of changes in the work environment that is happening quickly demanding their ability to adapt to the phenomenon of change that is happening, analyze the impact on the organization, and prepare the plans to deal with these changes. Therefore, the role of human resource management in the organization is not only about administration but also refers to the ability to develop the potential of human resources to be creative and innovative.

The work atmosphere is defined as the perception of the organizational policies, practices, and procedures that are accepted by individuals in organization or individual perceptions about the workplace [1]. A similar statement stated by Ballout that the work atmosphere is related to the environment that exists or is faced by someone who is in an organization, affect someone who is doing a task or a job [2]. The work atmosphere at the level of individuals and organizations, when the work atmosphere enters the individual order, it is called a psychological climate

In the process of change in government organizations will certainly have an impact on the organization's internal environment of the government. This change can be seen from the organizational situation and the employee's behavior. Differences in individual attitudes and situational circumstances in the workplace are important elements of career commitment [3]. Career commitment is said to be positive if an employee is able to show a high interest in learning, increase the knowledge, and delivered the knowledge to others [3]. Employees who have a strong level of career commitment and able to make their own career expectations in the future will make significant changes in the completion of tasks and responsibilities at this moment of their career.

The good changes in work environment towards organizational forms or career path in positive organizational has caused an employee in the organization has a higher commitment to their career paths and will affect the lack of commitment to their organization [3].

In the office of the Regional Personnel Agency of Bima Regency shows that the decrease of employees commitment caused some employees still feel the workplace is not comfortable, the narrow and moist workspaces, bad air flow, room settings are not good, lack of cooperation and support between employees in doing a job, the assignment of responsibilities and roles of employees that have not been maximized by the leadership, supporting facilities and infrastructure that are not complete in doing the job. These conditions cause dissatisfaction of employees in doing the job and affect on career commitment of its employees.

The work atmosphere is defined as the perception of the organizational policies, practices, and procedures that are accepted by individuals in organization or individual perceptions about the workplace [4]. A similar statement stated by Pramono, in which the work atmosphere is related to the environment that exists or is faced by someone who is in an organization, affect someone who is doing a task or a job [5]. There are several indicators that influence the work atmosphere: organizational structure, policies, technology and external environment [6]. The commitment will motivate and trigger someone to act better, because commitment is affecting someone's response so that it can trigger employees to do something better.

It is stated that career commitment is someone's attitude towards their work [7]. The definition of career commitment then develops into a subjective dimension of career, which is 
defined as a concept that influences and represents the identification with employment relationships in a specific field and behaviorally expressed through the ability to resolve dissatisfaction in finding the career goals. A similar statement stated by Haslam, in which the work atmosphere is defined as the perception of the organizational policies, practices, and procedures that are accepted by individuals in organization or individual perceptions about the workplace [1]. There are four indicators of career commitment that salary achievement and promotion, career attitude, career adaptation skills, and career identity [1].

The purpose of this study was to find out the effect of the work atmosphere on career commitment at Regional Personnel Agency office in Bima Regency.

\section{RESEARCH METHOD}

This research is an associative research with quantitative research [8]. The research location was at Regional Personnel Agency office in Bima Regency for 2 months. The population in this research was the Civil Servants at the Regional Personnel Agency office in Bima Regency, which amounted 43 people and the sample of this research was all the Civil Servants at the Regional Personnel Agency office in Bima Regency. The sampling technique used in this research is the saturation sample technique. Analysis of the data in this research used a simple linear regression with SPSS 16 for windows.

The hypothesis of this study is estimated that the working atmosphere affects the career commitment employees at Regional Personnel Agency office in Bima Regency.

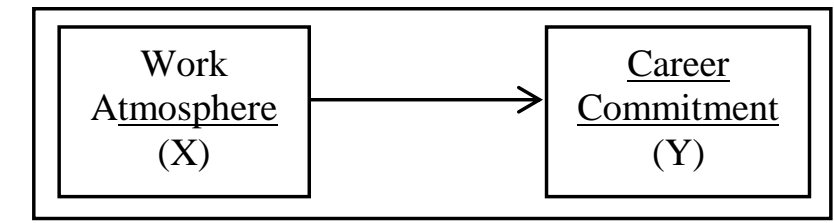

Fig. 1. Research Conceptual Framework

\section{RESULTS AND DISCUSSION}

TABLE I. TEST RESUlTS OF T

\begin{tabular}{|c|c|c|c|c|c|}
\hline \multicolumn{6}{|l|}{ Coefficient's $^{\text {'s }}$} \\
\hline \multirow[t]{2}{*}{ Model } & \multicolumn{2}{|c|}{$\begin{array}{c}\text { Unstandardized } \\
\text { Coefficients }\end{array}$} & \multirow{2}{*}{\begin{tabular}{|c|}
$\begin{array}{r}\text { Standardized } \\
\text { Coefficients }\end{array}$ \\
Beta \\
\end{tabular}} & \multirow[t]{2}{*}{$\mathbf{T}$} & \multirow[t]{2}{*}{ Sig. } \\
\hline & B & $\begin{array}{c}\text { Std. } \\
\text { Error }\end{array}$ & & & \\
\hline (Constant) & 16.392 & 3.739 & & 4.384 & .000 \\
\hline $\begin{array}{l}\text { Organizational } \\
\text { Atmosphere }\end{array}$ & 2.248 & .830 & 4.363 & 2.708 & .010 \\
\hline
\end{tabular}

The results of the t-test statistics for variables obtained $t$ score of 2.708 with $t$ table score of $2.019(2.708>2.019)$ with a significance score of 0.010 smaller than $0.05(0.010$ $<0.05$ ), which means "Work Atmosphere affect Career Commitment". If the working atmosphere is more conducive, it will affect the employees to increase their enthusiasm to commit to their careers. The creation of a positive work atmosphere needs to be done considering the completion of work assignments requires support from the surrounding environment so that the employees will be able to complete their work properly. Commitment is created when employees are able to complete the jobs on time with satisfactory results in order to make employees get a positive response from the leadership.

The finding of this study is in line with the finding of a study conducted by Charles L. Salindeho [9], in which work atmosphere has a significant correlation with career commitment, which means that if the work atmosphere is conducive, the employees will be more motivated to do the work well. The success of an organization is determined by its human resources. Good working atmosphere and positive career development will encourage and develop work commitment of the employees in a firm or an organization.

\section{CONCLUSION}

Based on the results of the analysis and discussion, it is found that the work atmosphere has a positive and significant effect on employee career commitment. In accordance with the results of this study, it is hoped that leaders pay more attention to the atmosphere in their work environment. If the work atmosphere is more conducive, the employees will be more motivated to do and complete the work properly. In addition, leaders need to use a persuasive approach with employees to find out the employee complaints about the work atmosphere in order not to cause the career commitment of employees to decrease.

\section{REFERENCES}

[2] S. A. Haslam, S. D. Reicher, and M. J. Platow, The new psychology of leadership: Identity, influence and power. Psychology Press, 2010.

[3] H. I. Ballout, "Career commitment and career success: moderating role of self-efficacy," Career Dev. Int., 2009.

[4] et al Gibson, Organisasi dan Manajemen Perilaku, Struktur dan Proses. 2008.

[5] S. P. Robbins, "Judge.(2008) Perilaku Organisasi," Jakarta: Salemba Empat

[6] A. Pramono, "Analisis Keterampilan Kerja Dan Iklim Kerja Terhadap Kualitas Pelayanan Keperawatan Di Ruang Rawat Inap RSU. H. Sahudin Kutacane." .

[7] S. P. Siagian, Sistem Informasi Manajemen. Jakarta: PT. Bumi Aksara., 2011.

[8] Sugiyono, Metode Penelitian Kuantitatif, Kualitatif dan R\&D. Bandung. Bandung: Afabeta, 2011.

[8] V. Riva'i and S. E. Jauvani, "Manajemen sumber daya manusia untuk perusahaan. jakarta: PT Raja Grafindo Persada,” 2009.

[9] Charles L Salindeho 2016. Pengaruh Iklim Kerja dan Pengembangan karir Terhadap Komitmen karir Dengan Kepuasan Kerja Sebagai Vaiabel Intervening. Jurnal Riset Bisnis dan Manajemen. Vol 4 No 3 